\title{
Effect of Finnsheep crossbreeding on Lamon sheep performance: post-mortem traits ${ }^{1}$
}

\author{
M. BONSEMBIANTE, I. ANDRIGHETTO and G. COZZI \\ Instituto di Zootecnica - Università di Padova \\ Via Gradenigo, 6 - 35131 Padova (Italy)
}

\begin{abstract}
This experiment was conducted in order to study the effects of crossbreeding of the local breed Lamon ( $\mathrm{L}$ ) with Finnsheep $(\mathrm{F})$, on the post-mortem performance of $\mathrm{F}_{1}$ lambs (FxL).

Nine $\mathrm{L}$ and $8 \mathrm{FxL}$ ram-lambs were fattened with a diet (11.6 MJ M.E./ $\mathrm{kg} \mathrm{d.m.)} \mathrm{based}$ on maize silage, dried sugar beet pulp and soybean meal, and slaughtered at $40.5 \pm 5.9 \mathrm{~kg}$ live weight at the age of 22 weeks.

Genotype did not affect dressing percentage on empty body weight (E.B.W.) but the crossbred lambs showed a lower incidence of the pelt $(18.4$ vs $20.2 \%$ on E.B.W.; $\mathrm{P}<.05)$ and a heavier empty digestive tract $(7.3$ vs $6.6 \%$ on E.B.W.; $\mathrm{P}<.05)$.

The conformation and composition of the carcass were similar for both genetic types; the hind quarter incidence was, however, reduced by the crossbreeding (43.8 vs $45.3 \%$ on total carcass; $\mathrm{P}<.05)$.

Meat samples from the FxL carcasses showed higher redness and saturation values than meat samples from L lambs. No significant differences were recorded for the cooking losses and the shear force.

In conclusion it appears that crossbreeding with $\mathrm{F}$ is not detrimental to the post-mortem performance of fattening $\mathrm{L}$ lambs.
\end{abstract}

Index words: Finnsheep, Lamon, crossbreeding, carcass composition, fattening lambs, meat quality

\section{Introduction}

Crossbreeding with Finnsheep $(\mathrm{F})$ is an interesting method of improving the moderate prolificacy of the Italian local breed Lamon (L).

\footnotetext{
1 Research project founded by Regione Veneto
}

A complete evaluation of the profitability of this crossbreeding must however also include an assessment of its effects on the low fat content and average muscularity which characterize the carcasses of $\mathrm{L}$ ram-lambs (1, $2,5,6)$.

The experiment reported here was carried out in order to compare the post mortem per- 
formance of purebred $\mathrm{L}$ and crossbred $\mathrm{F} \times \mathrm{L}$ lambs.

\section{Material and methods}

Nine $\mathrm{L}$ and $8 \mathrm{~F} \times \mathrm{L}$ lambs, weaned as previously described (4) at the "Legnaro Experimental Farm» of Padua University, were utilized.

The animals were fattened on a diet of maize silage, dried sugar beet pulp and soybean meal (11.6 MJ M.E. $\left.\cdot \mathrm{kg} \cdot \mathrm{d} . \mathrm{m}^{-1}{ }^{-1}\right)$ and were slaughtered at an average live weight of $40.5 \pm 5.9 \mathrm{~kg}$ following the usual procedure of the "Istituto di Zootecnica" of Padua (3).

The carcasses were measured and dissected according to the E.E.C. standard method (8) and the lean meat, separable fat and bone contents were determined. Colour (Hunter L.a.b, system), cooking losses and shear force were also measured on $m$. quadriceps femoris, $m$. semitendineus and $m$. semimembranaceus.

All experimental data were analyzed according to the following linear model (SPSS/PC):

$Y_{i j k}=\mu+G_{i}+S_{j}+G_{i j}+E_{i j k}$

where:

$\mathrm{Y}_{\mathrm{ijk}}=$ experimental datum;

$\mu \quad=$ general mean;

$\mathrm{G}_{\mathrm{i}}=$ fixed effect of the $\mathrm{i}^{\mathrm{th}}$ genotype $(1=\mathrm{L}$; $2=\mathrm{F} \times \mathrm{L}$ );

$\mathrm{S}_{\mathrm{j}} \quad$ = fixed effect of slaughtering day $(1-2)$;
$\mathrm{GS}_{\mathrm{ij}}=$ genotype $\times$ slaughtering day order interaction;

$\mathrm{E}_{\mathrm{ijk}}=\operatorname{residual}\left(0, \sigma^{2}\right)$.

As the effect of slaughtering day and interaction were never significant in the tables only the adjusted least square means of the genotype effects are reported.

\section{Results and discussion}

Genetic type did not affect dressing percentage ( $\%$ Empty Body Weight - E.B.W.) which was on average $(54.3 \%)$ similar to that recorded in previous experiments $(3,6)$ (table 1).

The crossbred $\mathrm{F} \times \mathrm{L}$ ram lambs showed a lower pelt incidence (18.4 vs $20.2 \%$ E.B.W.; $\mathrm{P}<.01)$ and a higher incidence of empty digestive tract $(7.3$ vs $6.6 \%$ E.B.W.; $\mathrm{P}<.05)$ than the purebred $\mathrm{L}$ lambs. This is in agreement with the infra-vitam results, as the $\mathrm{F} \times \mathrm{L}$ lambs exhibited a higher dry matter intake (4).

Confirming experiments carried out previously $(7$,$) , the crossbred \mathrm{F} \times \mathrm{L}$ lambs were characterized by heavier total internal fatty deposits.

Carcass conformation was similar for both the genetic types, whereas the crossbred lambs showed a lower hind quarter incidence (43.8 vs $45.3 \%$; $\mathrm{P}<.05$ ) (table 2 ).

The carcass composition of the crossbred lambs was similar to that of the purebred lambs and previous experiments (1).

Table 1. Post-mortem traits.

\begin{tabular}{|c|c|c|c|c|}
\hline & & \multicolumn{2}{|c|}{ Genotype } & \multirow{2}{*}{$\begin{array}{l}\text { Residual variance } \\
\quad(14 \mathrm{~d} \text {. of } \mathrm{f} .)\end{array}$} \\
\hline & & L & $\mathrm{F} \times \mathrm{L}$ & \\
\hline Slaughter live weight & $\mathrm{kg}$ & 39.4 & 41.6 & 34.85 \\
\hline \multicolumn{5}{|l|}{ Incidence of E.B.W.: } \\
\hline - carcass & $\%$ & 54.1 & 54.4 & 3.05 \\
\hline - head & $\%$ & 4.6 & 4.8 & 0.16 \\
\hline - fore and hind legs & $\%$ & 2.8 & 2.6 & 0.11 \\
\hline - pelt & $\%$ & $20.2^{\mathrm{b}}$ & $18.4^{\mathrm{a}}$ & 2.91 \\
\hline - empty digestive tract & $\%$ & $6.6^{a}$ & $7.3^{\mathrm{b}}$ & 0.51 \\
\hline - total internal fatty deposits & $\%$ & 2.6 & 3.3 & 0.45 \\
\hline - lights $(*)$ & $\%$ & 4.9 & 5.3 & 0.15 \\
\hline
\end{tabular}

(*) Oesophagus, trachea, lungs, heart and liver.

a, b: $\mathrm{P}<.05$ 
Table 2. Carcass composition ( $\%$ carcass weight).

\begin{tabular}{|c|c|c|c|c|}
\hline & & \multicolumn{2}{|c|}{ Genotype } & \multirow{2}{*}{$\begin{array}{l}\text { Residual variance } \\
\text { (14 d. of f.) }\end{array}$} \\
\hline & & L & $\mathrm{F} \times \mathrm{L}$ & \\
\hline Hind quarter & $\%$ & $45.3^{\mathrm{b}}$ & $43.8^{\mathrm{a}}$ & 1.01 \\
\hline Total lean meat & $\%$ & 63.6 & 65.1 & 2.84 \\
\hline Total separable fat & $\%$ & 12.9 & 12.1 & 4.87 \\
\hline Bone and tendons & $\%$ & 23.5 & 22.8 & 6.00 \\
\hline
\end{tabular}

a, b: $\mathrm{P}<.05$

Table 3. Meat redness and saturation.

\begin{tabular}{|c|c|c|c|}
\hline & \multicolumn{2}{|c|}{ Genotype } & \multirow{2}{*}{$\begin{array}{l}\text { Residual variance } \\
\text { (14 d. of } \mathrm{f} .)\end{array}$} \\
\hline & $\mathrm{L}$ & $\mathrm{F} \times \mathrm{L}$ & \\
\hline \multicolumn{4}{|l|}{ Redness $\left(a_{1}\right)$ : } \\
\hline - m. quadriceps femoris & $16.3^{\mathrm{a}}$ & $17.5^{b}$ & 0.72 \\
\hline$-m$. semitendineus & 17.9 & 18.8 & 2.80 \\
\hline - m. semimembranaceus & $19.0^{4}$ & $21.3^{\mathrm{B}}$ & 2.33 \\
\hline \multicolumn{4}{|l|}{ Saturation (S): } \\
\hline - m. quadriceps femoris & $18.2^{\mathrm{a}}$ & $19.4^{b}$ & 1.06 \\
\hline - $m$. semitendineus & 2.03 & 21.4 & 3.85 \\
\hline - m. semimembranaceus & $22,1^{\mathrm{a}}$ & $24.4^{b}$ & 2.84 \\
\hline
\end{tabular}
A, B: $\mathrm{P}<.01$
a, b: $P<.05$

Lightness, yellowness, hue, cooking losses and shear force of the muscles were unaffected by Finnish crossbreeding, whereas redness and saturation were enhanced (table 3 ).

\section{Conclusions}

The results of this experiment confirm the positive judgement of $\mathrm{F}$ crossbreeding on $\mathrm{L}$ sheep, as the crossbred $\mathrm{F} \times \mathrm{L}$ ram-lambs showed post-mortem performances comparable to those of the purebred $\mathrm{L}$ ram-lambs.

Investigations are now in progress in order to study the role of additive genetic, heterotic and maternal effects in determining the good performance of the crossbred $\mathrm{F} \times \mathrm{L}$ lambs.

\section{References}

1. Andrighetto, I., Bittante, G., Ramanzin, M. \& BAILONI, L., 1988. (In press).

2. Bittante, G., 1988. Unpublished data.

3. Bittante, G., Andrighetto, I., Ramanzin, M. \& Spanghero, M., 1988. (In press).

4. Bittante, G. \& Pastore, E., 1988. Effect of Finnsheep crossbreeding on Lamon sheep performance: in vivo traits. J. Agric. Sci. Finl. 60: 511-514.

5. Bonsembiante, M., Bittante, G., Andrighetto, I. \&

Ramanzin, M., 1982. Agricoltura delle Venezie, 36, $343-360$.

6. Bonsembiante, M., Bittante, G., Andrighetto, I. \& Ramanzin, M., 1988. Zoot. Nutr. Anim., 14, 5-20.

7. Maijala, K. \& Österberg, S., 1977. Liv. Prod. Sci., 4, 355-377.

8. Williams, D.R. \& Bergstrom, P.L., 1980. Anatomical jointing, tissue separation and weight recording: E.E.C. standard method for beef, Commission of the European Communities, EUR 6878 EN. 